\title{
On Financial Report Problems and Improvement Measures of Listed Companies
}

\author{
Yiji Chen
}

Jiujiang University

527218817@qq.com

Keywords: audit, economic responsibility audit, synchronous audit

\begin{abstract}
Based on discussion of meaning and causes of economic responsibility audit risk, this paper proposes prevention measures for economic responsibility audit risk.
\end{abstract}

\section{Introduction}

Listed companies refer to limited liability companies that legally issue public shares with its shares listed and exchanged in Stock Exchange after obtaining approval of Stock Exchange. Compared with general companies, the biggest feature of listed companies is that they can take advantage of stock market to raise funds and thus widely absorb idle funds in society. Financial report information relatively completely reflects company's financial position, operating results, cash flows and other relevant information, and therefore it is at the core of information disclosure of listed companies. Specifically, significance of listed companies' financial reports is reflected in three aspects.

\section{Significance of Financial Report for Listed Companies}

2.1 Maintenance of normal order of stock market. Sound financial report disclosure not only inhibits fraud of listed companies' information, but also attacks black-box operation in stock market, which, to a certain extent, avoids artificial share price manipulation with listed companies' information by listed companies and some institutions. Effective information disclosure of listed companies' financial report is an important means to regulate the market order and safeguard market efficiency. To maintain good order of stock market, standardized information operation mechanism of listed companies must be established to promote rational allocation of social resources.

2.2 Protection of interests of medium and small investors. Effective information disclosure of listed company financial reports can ensure equal access to necessary information of information users, thereby protecting legitimate rights and interests of investors, especially small investors, and other interests of the public, so that they have equal access to necessary relevant information when they make relevant decisions, and seeking of improper interests by information monopoly through irregular channels by minority body can be prevented.

2.3 Implementation of corporate management responsibilities. On the one hand, disclose of financial reports by listed companies can help a range of external information users acquire information on quantitative aspects of the company's financial condition, operation results, financial condition changes, etc. in the economic decision-making; on the other hand, it can provide 
administering authorities with control information or resource management efficiency and other information. Therefore, through disclosed company information, operating management responsibility of administrative staff can be implemented, which earnestly ensures safety of companies' resources and its full effective use, thus maximizing interests of shareholders and society.

\section{Deficiencies in Current Listed Companies' Financial Report}

Financial statements still play an important role in the current financial report system. With social and economic development and under a variety of ever-changing needs for global market, requirements and expectations of the public for information quality of listed companies' financial report are increasingly higher. Currently, financial report is facing criticism from all sides. The focus of criticism is that company financial reports fail to keep pace with the times of rapid change and provide valuable information, and that financial statement information is no longer relevant. Specifically, deficiencies in the current financial report are mainly demonstrated in the following aspects.

\subsection{Deficiencies in Recognition and Measurement}

First, recognition criteria of traditional accounting are on the basis of past transactions of a subject, and future transactions and events are not recognized. It is difficult for traditional accounting based on single historical cost measurement model to fairly reflect those assets prone to changes or real value of liabilities in period-end financial statements. Second, current financial report model focus only on inventory, plant, machinery equipment and other physical assets, less concerned about intangible assets such as intellectual property, science and technology and human resources. In today's economic environment, future company cash flows and motivation of market value are attracting increasingly more attention, but the information is not revealed in current financial reports. With emergence of a large numbers of high-tech companies and arrival of knowledge economy era, measurement and disclosure of intangible assets, goodwill and human capital is becoming increasingly important. Wolman (1996) believes that traditional financial statements are less capable of reflecting wealth-creating assets than before, and that financial report is caught in predicament of accelerated losing of its usefulness. He believes that a considerable number of assets is underestimated by historical cost accounting, and not only this, assets has not been fully confirmed, the problem is still deteriorating, and he is deeply worried about financial accounting and report's failure to keep pace with change in commercial activities.

\subsection{Deficiencies in Identification of Gains and Losses and Information Disclosure}

Since the 1930s, income statement has attracted widespread concern of information users. In financial statements, no other figures can attract more attention from investment classes than earnings per share. The degree of concern of price earning ratio reflects its significance. Littleton (1989) repeatedly stresses importance of income statement in his book "Theoretical Structure of Accounting". However, increment of value will not be reported at generation, but postponed until realization, which will lead potential time error in identification of earnings. Current financial report lays too much emphasis on single measurement of earnings. In a world with increasing complexity, no single data can capture all aspects that impact wealth change in each reporting period. Current income statement is unable to meet requirements of 21 st century market economy.

\subsection{Deficiencies in Satisfying Requirements of Timeliness}


Timeliness of financial report has seriously affected information relevance. Timeliness of report means when to disclose the most appropriate problems for financial report. Under the premise of continuing operations, in theory, profit achievement of accounting entity can only be accurately calculated by collection and comparison of income and expenses at the final end of all production and operation activities by accounting entity. But this will not work in practice as company investors, creditors and managers need to keep abreast of operation of enterprises. As a result, issue before accounting personnel is to determine when to start and when to stop business accounting of economic activities. In traditional practice, financial reports provided by enterprises to outsiders are generally compiled annually, quarterly or monthly, etc. at fixed time basis and published periodically. But now, as competition intensifies, science and technology progress and financial instrument change with each passing day, there are dramatic changes in economic situation. In particular, capital market has entered the era of rapid development, so whether timeliness of financial report can continue to meet information users' needs for financial report is quite worthy of suspicion. Since users' corporate investment and credit decisions often need to go through continuous analysis and assessment procedures before decision, to meet information needs of users, more flexible financial report in a shorter period of time should be provided to outsiders.

\subsection{Deficiencies in Information Disclosure Channels and Media of Financial Report}

Channels and media of information disclosure refers to the problem of means of provision of financial report information. Standard, general-purpose financial report model is an effective means for enterprises to deliver financial information to users. However, this general type of report inevitably ignores differences of various different users in information needs and usage, as in terms of users, some are accustomed to use of integrated information, while others are used to use of detailed information, some tend to use qualitative information, while others tend to use quantitative information; different information users may have different preferences for recombination of these four information types. In addition, some users like to use information in text and digital description, while others like to use visual information such as charts, images. Therefore, how to properly resolve the difference in use of such information presents new challenges to future way of information disclosure.

\section{Ideas and Measures for Improvement of Financial Reports of Listed Companies}

\subsection{Improve Diversity of Measurement Basis of Financial Report}

With development of era, changes in user needs and economic globalization, historical cost information, a traditional measurement basis, is no longer the only reliable source of information, and fair value measurement model will be widely used in practice. In development of the existing guidelines, United States, Britain, Canada, Australia and the International Accounting Standards Committee employ concept of fair value more widely. China's "Enterprise Accounting Standards" (2006) gradually integrates with International Accounting Standards and this measurement property is also introduced in specific accounting standards such as financial instruments, investment real estate, and enterprise merging not under common control, debt restructuring and non-monetary transactions. Therefore, in future financial reports, equal importance should be attached to historical value and fair value measurement, with information of fair value pricing provided with historical pricing information as a supplement. 
Information

Future financial report aims to provide users with information helpful for decision-making, which includes not only disclosure of company's existing internal financial information, but also disclosure of external business-related information, such as industrial policy, price policy, market information, industry information, company's environment of competition, etc. that impact business decisions; not only disclosure of business-related financial information, but also disclosure of business-related non-financial information, such as enterprise asset quality, non-performing assets status, cost level, firm size, debt records, etc.; not only disclosure of afterwards enterprise information, but also disclosure of forward-looking information, such as business prospects, earnings forecast, prospect planning of business authorities; not only disclose of certain information, but also disclosure of some uncertain information with disclosure of risk information strengthened. Meanwhile, future financial report will increase disclosure of relative value information in information disclosure, as relative value information is more comparable and can better meet the needs of decision-making.

\subsection{Expand Disclosure Way of Financial Report}

With development and progress of information technology, future financial report will provide real-time report, notable feature of which is that information user can obtain the latest financial report from the network at any time, without having to wait until the end of an accounting period. The timely processing of information and readily available features greatly enhances timeliness of financial report. Meanwhile, provision of financial report no longer rigidly adheres to one form, still reports, text-based, but more vivid form of graphics, video and audio, etc. could be supplemented, so that report is audio-visual with illustrations and pictures, which makes information expression more vivid and intuitive, more easily accepted and understood by users, so as to meet needs of information users of different types in all angles. Also, interactive reports will become the mainstream of future financial report. Report companies are closely linked with information users through computer network. On the one hand, report companies publish online a variety of provided accounting reports and information for users to choose; on the other hand, financial report users may also initiatively put forward information needs through the network, so that report companies make pointed improvement of financial report. With such interactive contact, financial report can be continuously improved to conform to the needs of information users.

\subsection{Improve Content System of Financial Report}

Future financial reports will need to add the following contents on the basis of current financial report: value added statement that comprehensively measures corporate social contribution in value creation, in order to provide information for national macro-control; provided social responsibility financial statements that reflect fulfillment of corporate social responsibility; difference financial statements differentiated in time and content for different users; statement of stockholder equity to meet the needs of maturing and development of joint-stock system reform, etc.

\section{Conclusion}

Financial report information is not only a major component of capital market information, but also derived source of other information. Listed companies' financial reports constitute the main basis of behavior decision by relevant stakeholders of capital markets. Perfect information disclosure system is of great significance for reducing uncertainty and risk in capital market. 


\section{References}

[1] Wang Hua. Financial Accounting Research Frontier [M]. Machinery Industry Press, 2008.

[2] Ge Jiashu, Chen Shaohua. Study on Improvement of Corporate Financial Report[M] Financial and Economic Publishing House, 2002.

[3] Bian Desheng. Building of New Financial Report System Based on Statement Users [J]. Heilongjiang Foreign Trade, 2009 (12)

[4]Liu Feng, Ge Jiashu Financial Report System Reconstruction [J]. Accounting Research, 2012 (03). 